This is a post-peer-review, pre-copy edited version of an article published in Policy and Politics. The definitive publisher-authenticated version Cairney P, Fischer M \& Ingold K (2018) Fracking in the UK and Switzerland: why differences in policymaking systems don't always produce different outputs and outcomes, Policy and Politics, 46 (1), pp. 125-147 is available online at: https://doi.org/10.1332/030557316X14793989976783 
Paul Cairney, Karin Ingold, and Manuel Fisher

\title{
Fracking in the UK and Switzerland: why differences in policymaking systems don't always produce different outputs and outcomes
}

Policy and Politics, forthcoming, 2016

\begin{abstract}
We address a key puzzle in policy studies: why don't major differences in political systems and policy produce major differences in policy processes, outputs, and outcomes? We show why key aspects of fracking policy are similar in the UK and Switzerland despite the UK majoritarian government being 'all out for shale' and Switzerland's consensus democracy favouring moratoriums. We use the 'advocacy coalition framework' and new survey data to show why differences in UK and Swiss processes are subtle. In both cases, actors cooperate and compete with each other by sharing information within and across coalitions."
\end{abstract}

\section{INTRODUCTION}

At first glance, UK and Swiss fracking policy and policymaking seem very different. The UK government is at the heart of a 'majoritarian' system which centralises policymaking and can impose policy from the top down, while many veto points clearly exist in Switzerland's 'consensus' democracy. The UK government is pro-fracking, while Swiss authorities have come out against it. In that context, the current lack of differences in their policy outcomes and policymaking styles are striking: why, if the UK Prime Minister is 'all out for shale' (Prime Minister's Office, 2014), and his government can impose policy, has there been limited commercial development and, in several important ways, a tendency to respect subnational policymaking? Why is policy and policymaking surprisingly similar in the UK and Switzerland?

There are two main answers to these questions: first, the UK Government is, in practice, not as unequivocally in favour of fracking as 'all out' suggests, and UK policymaking is generally not the 'top down' polar opposite of Swiss policymaking. Second, the macro-political context, in which the majoritarian and consensus labels seem like contrasting archetypes, does not have a decisive impact. In other words, many other factors affect policymaking, policy outputs and outcomes, and the macro-political context has an indirect influence on them, at best. In particular, there are common pressures on central governments to share regulatory functions with many other bodies. They also exhibit the same reliance on policy subsystems in which coalitions of actors (a) cooperate within coalitions, and compete with others, to share information designed to give them the upper hand in policy debate, or (b) cooperate to some extent across coalitions to negotiate policy compromise. Their policy processes are not identical, but the differences are more subtle than one expects if the main frame of reference is macro-politics.

We explain these dynamics in three ways. First, we establish a new way to help answer a fundamental question in politics: what is the effect of macro-political factors on policy and policymaking? This question has long been at the heart of comparative studies, but debates between classic explanations of policymaking remain unresolved. One literature emphasizes 
the importance of the macro-political institutions of political systems. It identifies contrasting archetypes and the often-misguided expectation for 'top-down' policymaking to produce quicker and more radical policy change in majoritarian systems (Lijphart, 1999). Another literature identifies important policymaking practices common to policy subsystems (Richardson, 1982), but does not track systematically the macro-political effect on subsystem dynamics.

In that context, these limitations in comparative policy studies can be addressed by theoretically informed systematic case study analysis which evaluates (a) the extent to which major institutional differences in political systems influence subsystem dynamics, and (b) the potential effect of those dynamics on policy outcomes. To that end, we use the Advocacy Coalition Framework (ACF) to compare subsystem practices, showing how actors with shared beliefs form coalitions, how they exchange information within and across coalitions, and how coalitions compete with each other to turn their beliefs into policy (Sabatier and Weible, 2007).

Second, we examine to what extent fracking policy change differs in the UK and Switzerland. In the case of fracking, policy change most often means a shift from the absence of clear policy to: (a) policy in favour of commercial fracking development; or (b) the introduction of clear regulations to halt or ban fracking activity. Only the UK government has gone 'all out for shale' and only the UK's national policymaking institutions can be exploited to promote this change quickly, but so far the effect on outcomes has been limited. The clearer output is in Switzerland, where fracking has been temporarily banned in the most relevant cantons, but UK and Swiss policy outcomes are very similar as little commercial fracking has taken place in either country.

Third, we ask to what extent fracking policymaking differs in the UK and Switzerland. We begin with the well-documented insight that contrasting political systems often produce similar processes: policymaking often happens at a decentralized level, and governments and other actors negotiate political settlements in subsystems. Yet, differences in macro-political context produce the possibility that the UK and Switzerland have distinctive subsystem dynamics.

We use a systematic comparative analysis, gathering the same type of data and applying identical methods to two 'most different' systems, to identify differences and similarities in the two countries, and link them to macro-institutional factors. We identify a non-trivial distinction between pro- and anti-fracking advocacy coalitions, and show how they share information to influence the policy agenda and policy outputs. In all systems, actors share information primarily with their allies in coalitions, but also with their competitors to aid negotiation. In the relatively competitive atmosphere of majoritarian systems, actors appear more likely to internalise the supply of information and refuse to share it with their competitors. Thus, macrolevel institutional differences do not necessarily cause differences in policy, but they influence the 'culture' of policymaking. Consequently, the macro-political context is important, but not in the simple ways usually expressed in comparative politics.

\section{The impact of contrasting macro-political institutions: do they cause major differences in subsystem dynamics?}


A key approach in comparative politics is to focus on formal macro-institutional structures of political systems. The point is made most strongly by Lijphart (1984; 1999: 5-7; see also Gallagher et al, 1995; Lane 2001): the UK and Switzerland represent contrasting institutional archetypes: 'majoritarianism', a unitary government structure, and 'top-down' policymaking characterizes the UK; while Switzerland is known for its 'consensus' democracy, federalist structure, and participative politics. Switzerland has an established culture of direct and regular participation via referendums (Vatter, 2009; Papadopoulos, 2001; Lijphart, 1999). Directdemocratic instruments oblige public authorities to negotiate policy solutions with minority groups. Federalism offers potential veto points and allows actors to defy a policy solution favoured by central government (Thorlakson, 2003; Linder and Vatter, 2001; Tsebelis, 1995). It contrasts with the alleged 'government knows best' approach of the 'British political tradition' (Cairney, 2011) even following governance reforms such as devolution (Flinders, 2010). In this limited comparison, consensus democracies encourage 'compromise and concertation' between government, regions, and interest groups; in majoritarian systems, there are fewer attempts by governments to compromise with, or build consensus among, different actors (Lijphart 1999: 5).

This approach assumes that there will generally be major differences in policymaking, and that they are best explained by divergent political systems. Policy change driven from the 'top' would be quicker and more substantive in the UK, since power is more concentrated in the centre and there are fewer 'veto points'.

An alternative, found in comparative policy studies, is to focus on where the action is: policy subsystems. When we go beyond reputations built on macro-political institutional analysis, we find striking similarities in policy processes within different political systems. Further, we should not assume that differences in policymaking can be attributed to macro-institutional differences, since they may depend on the policy context and specific series of events and decisions in each country.

The latter point is central to contemporary public policy analysis: the UK's 'majoritarian' image has long been challenged in comparative studies (Richardson, 1982), and its alternative image as 'consultative and non-radical ... has been reinforced in an impressive number of studies comparing British policymaking with that of other countries and the European Union' (Jordan and Cairney, 2013: 240; Cairney and Widfeldt, 2015; Cairney, 2011; Cairney, 2012: 88-91). Early studies showed that UK central government is the home to many 'policy communities' composed of civil servants and groups. These findings have become reinforced by modern developments: the UK shares responsibility with the European Union, has devolved many responsibilities to governments in Scotland, Wales, and Northern Ireland, and does not impose policies on local government by default. Adam and Kriesi (2007: 140) argue that the formal concentration of power in Britain does not help predict how it is used, while Kriesi et al.'s (2006: 357-8) comparative empirical study suggests that 'national level generalizations about power configurations and policy processes' are unreliable since British subsystems resemble 'more closely those expected for consensus than for majoritarian democracies'. We should not assume that macro-politics will profoundly affect the nature of the subsystem dealing with particular issues. 


\section{Using the Advocacy Coalition Framework to compare subsystem dynamics}

Using the Advocacy Coalition Framework (ACF) has at least three theoretical and empirical advantages. First, the ACF defines key elements important to describing and understanding policy-making in subsystems, thus helping a systematic comparison across countries. Second, the ACF is conducive to the study of subsystems within a broader institutional context: it takes into account the macro-political differences identified by comparative studies of political systems to identify the context for actors' interaction, while focusing primarily on actors and coalitions in subsystems (Sabatier and Jenkins-Smith, 1993; Sabatier, 1998; Weible et al, 2009; Jenkins-Smith et al, 2014; Mahoney, 2007, Sabatier and Weible, 2007). Third, we can generate new insights on the ACF, which began as a way to explain US policy dynamics, by comparing multiple European experiences. Such comparative ACF studies taking into account the macroinstitutional context are rare (Lubell, 2003). Overall, we are applying and enhancing the value of the ACF.

The ACF suggests that individuals and collective actors engage in politics to translate their beliefs into policy solutions. Actors with shared beliefs form coalitions to cooperate with each other, and compete with coalitions with opposing beliefs (Sabatier, 1988: 139; Cairney, 2015). Coalitions are composed of actors 'from a variety of positions (elected and agency officials, interest group leaders, researchers) who 'show a non-trivial degree of coordinated activity over time' (Sabatier, 1988: 139). Beliefs can range from 'core' that are difficult to change, to 'policy core' that are still deep-seated, but more specific and related to one policy subsystem, and 'secondary aspects' linked to technical matters on how policy aims should be met.

A key aspect of interaction between and within coalitions is the process in which actors share information. Information exchange is crucial, as policymakers are boundedly rational and, by necessity, have to make decisions in the face of uncertainty (Simon, 1976; Zahariadis, 2007; Walker et al., 2013; Newig et al., 2005; Sigel et al., 2010; Metz and Ingold, 2014; Lubell 2013). Indeed, uncertainty can be used strategically. Some actors portray issues as clear and straightforward, and others stress uncertainty (Newig et al., 2005). Policymakers then decide who, and what information, to trust, to help them develop a sense of risk associated with any decision. Actors debate risk in relation to potential reward; and, policymakers weigh up the risks of their actions in terms of the problem and the effect of their decision in relation to their popularity and other aims. In other words, 'evidence-based policymaking' is a political process, involving competition to decide what information counts (Cairney, 2016; Ingold and Gschwend, 2014).

Policymakers also make decisions in the face of ambiguity, which regards the ways in which policy problems are framed. Actors can entertain many ways to understand an issue. Policymaking involves persuasion to encourage people to think about issues primarily in terms of their positive or negative aspects; or, the potential for events, media, and powerful actors to shift attention to one at the expense of the other (Dearing and Rogers, 1996: 1; Baumgartner and Jones, 1993: 11-2; Kingdon, 1984: 3-4; Cairney, 2012: 183). 
The ACF suggests that coalition partners primarily share information with each other and seek to exclude actors from opposing coalitions. They are particularly careful with political information on strategies designed to frame problems and influence which level of government should have responsibility for policy. Yet, actors also engage in more technical debates on science and risk, and they are often expected to do so with their competitors. One coalition may try to promote technical information to reduce the appearance of uncertainty. Another may exploit uncertainty and challenge the status of technical information to highlight the risks of policy change. Consequently, we show how actors promote or block the exchange of technical and political information within and across coalitions.

\section{Fracking policy: unequivocal opposition in Switzerland, tentative support in the UK}

One expectation, based on the UK Government's stance backed by its macro-political institutions, is that rapid and substantial policy change in favour of fracking is more likely in the UK. Yet, we do not find evidence of this major shift. Instead, it generally promotes supportive economic and regulatory measures to reduce the planning burden on firms (in the Infrastructure Act 2015), and increase financial incentives for local communities (BBC News, 2014; The Guardian, 2015). Its strategy is to provide the conditions for private companies to decide (following test drills) how economically viable their operations will be (DECC, 2012; 2014a: 26-8; 2014b: 6; White et al., 2014: 4-6). These moves are reinforced by measures to encourage preliminary development, including: tax breaks on capital investment; the promise of government compensation to local areas (DECC, 2013b; HM Treasury, 2013; BBC News, 2014 - note that 'the Crown' owns the mineral rights and the government would collect and administer the compensation - Beebeejaun, 2013); the reform of planning guidance for England to reduce obstacles to development (Jones et al., 2014b: 357); and, a pro-fracking public engagement strategy (DECC, 2014c; Sciencewise, 2013).

This approach has produced many pro-fracking policy outputs but they have not translated into many concrete outcomes, partly because central government is a key actor but not the sole decision maker. It has overall responsibility for energy policy, retains ownership of mineral and gas resources, provides licenses for private companies to operate, and in England retains the right to overrule local planning decisions. However, it has left crucial aspects of policy to devolved governments, responsible for the national planning guidelines which to all intents and purposes give them a veto on development (Cairney et al, 2016). It has also maintained the ability of English local authorities to control planning permission for drilling sites, albeit while changing the planning rules to increase the likelihood of planning permission, and retaining the right to 'call in' applications of national importance. While it has signalled its support for development in particular areas, including the North West of England, it has not gone 'all out for shale' in the sense of imposing commercial development on local areas. Instead, it accepts its part of a multi-level process which includes the need for companies to have licenses from DECC and multiple public bodies (such as the Environmental Agency) and planning consent from devolved and local areas (DECC, 2013a: 10; DECC, 2013b: 10). Scotland will also receive licensing powers from the Scotland Act 2016. Many of these points of consent represent new 'venues' for anti-fracking actors to slow down the process (House of Lords Economic Affairs Committee, 2014: 6-7). For example, in 2015, the Scottish and Welsh governments 
introduced moratoriums and Lancashire council rejected a major planning application (Cairney et al, 2016).

In the federalist system of Switzerland, the exploitation and use of natural resources in the underground is regulated in a decentralized way. Cantons have a mineral royalty law that regulates the use of those resources and gives the competence to the canton to distribute concessions to firms. No fracking can take place without the express permission of cantons. The permission procedures have to take into account the protection of natural resources, drinking water and ecosystems, which are regulated by national law.

Hydraulic fracturing has been a policy issue mainly in three Swiss cantons - Neuchâtel, Bern and Vaud - and policy differs slightly among them. In Neuchâtel, Celtique Energie engaged in a preliminary discussion with cantonal authorities about exploration for any type of gas drilling. Its proposed drilling project in Val-de-Travers induced public opposition and parliamentary initiatives. This led to a moratorium in 2014 on all development for ten years, and a new cantonal mining law will ban shale gas exploration and extraction. In Bern, Seag and Celtique Energie hold exploration concessions. The parliamentary initiative asked for the opinion of the cantonal government on the prospective use of fracking, which was critical but did not envision a legal ban. Consequently, the cantonal Green party and environmental organizations started a successful popular initiative to incorporate a ban in the revision of the mineral royalty act. The first canton passing a moratorium on shale gas extraction was Vaud in 2011, following neighbouring France. It was installed following a parliamentary interpellation, arguing that risks and environmental dangers are too high and national coordination should be installed first. Development is suspended (although three gas companies previously held exploration concessions, and one received drilling permission and found gas). To sum up the Swiss situation, veto rights were activated and local political initiatives undertaken in all three regions under consideration. The issue of hydraulic fracturing was not (yet) shifted on the national level, but direct-democratic instruments are as strong on the national as on the regional and local levels in Switzerland. This is why we would expect similar strong opposition, and thus similar outputs and outcomes on the national level, as now on the regional one. Until now, however, one has to note that general public attention, and national media coverage of the issue of hydraulic fracturing is almost absent in Switzerland.

Clearly, there are differences in British and Swiss policy statements which have translated into some key differences in outputs: each Swiss canton has halted development and, although the UK's devolved regions have supported similar moratoriums, the ability of English local authorities to oppose development is still unclear. Yet, their outcomes remain similar: there is very little commercial development in either country. Indeed, we do not know if a recent decision to approve development by North Yorkshire county council (the first approved development of its kind since 2011 - BBC News, 2016) marks the beginning of major commercial development across England or a key exception. This is a striking statement given that the UK Prime Minister stated such unequivocal support. The UK's political choices have not been reinforced by a top-down policy style associated with its majoritarian macro-political design, suggesting that its subsystem could resemble that 'expected for consensus than for majoritarian democracies' (Kriesi et al, 2006: 357-8). 


\section{Advocacy coalitions in the UK and Switzerland: Survey and data}

We describe advocacy coalitions and their relations based on a major new survey to explore these potential similarities in the formation and operation of fracking subsystems, albeit at a different territorial scale to reflect the initial division of responsibilities in each country. At their heart is a process of coalition formation, based partly on the beliefs of participants, and a competition between coalitions to set the policy agenda. Put simply, we aim to explain the direction of policy in terms of the structure of, and interactions within and across, coalitions. We focus primarily on information exchange. The main currency in policy debate is information: technical information to influence the scientific debate on the risks of fracking, and political information to influence the primary way in which policymakers understand the policy problem.

We use empirical data gathered in surveys among key actors to identify advocacy coalitions and the ways in which they exchange information. We identify key actors, in the public and private sector, based on an in-depth analysis of official documents, media articles and secondary sources, and use positional (actors' formal competence), decisional (their process participation) and reputational (power perception by experts and peers) analyses of networks (Laumann et al., 1983). For the UK, this resulted in a list of 34 organizations; for Switzerland, a total of 34 actors for Neuchâtel, 27 for Bern, and 25 for Vaud. Response rates reached 53\% in the UK, and 65\%, 74\% and 48\% in Neuchâtel, Bern, and Vaud. ${ }^{1}$ For the identification of advocacy coalitions in Switzerland, we excluded some actors (mainly because of partial nonresponses) and include 30 actors for Neuchâtel, 23 for Bern and 22 for Vaud. In all cases, the same survey questions and methods guided the identification of coalitions (first based on agreement and disagreement relations, then validated via belief assessment $)^{2}$, their problem and uncertainty perception, policy preferences, and information exchange (see online Appendix I).

\section{What is the nature of advocacy coalitions in the UK and Switzerland?}

Based on agreement and disagreement relations ${ }^{3}$, we find evidence for two main advocacy coalitions in both countries. A pro-exploration coalition, in favour of determining the commercial potential of fracking, opposes an anti-fracking coalition. Table 1 displays mean values of beliefs and perceptions per coalition and case. In all four cases, the anti-fracking coalition perceives problems related to risks and environmental uncertainties much more seriously than the pro-exploration coalition. To reduce risks and uncertainties, anti-fracking members would like to rely on stronger state intervention and enhanced pro-environmental regulation (with the exception of the anti-fracking coalition in Vaud) such as water and air quality controls and chemicals disclosure (see online Appendix I, questions 9, 10 and 11). The latter confirms its perspective that fracking is primarily a potentially economically beneficial measure to improve the region's or country's competitiveness on the energy market (albeit from limited information, as many actors did not respond to some questions - see note below Table 1). 
Table 1: Mean values in coalition beliefs

\begin{tabular}{|c|c|c|c|c|}
\hline $\begin{array}{l}\text { Coalitions per } \\
\text { case and } \\
\text { country }\end{array}$ & Stop fracking & $\begin{array}{l}\text { Problems } \\
\text { related to } \\
\text { fracking }\end{array}$ & $\begin{array}{l}\text { Pro-environ. } \\
\text { fracking } \\
\text { regulation }\end{array}$ & Core beliefs \\
\hline & $\begin{array}{l}1=\text { absolutely } \\
\text { not } \\
4=\text { stop } \\
\text { completely }\end{array}$ & $\begin{array}{l}1=\text { no concern } \\
4=\text { serious } \\
\text { problems } \\
\text { identified }\end{array}$ & $\begin{array}{l}1=\text { not necessary } \\
4=\text { absolutely } \\
\text { necessary }\end{array}$ & $\begin{array}{l}1=\text { individual } \\
\text { market } \\
\text { freedom } \\
4=\text { state } \\
\text { intervention }\end{array}$ \\
\hline $\begin{array}{l}\text { Pro-exploration } \\
\text { UK }\end{array}$ & $\begin{array}{l}2.22 \\
(n=9)\end{array}$ & $\begin{array}{l}2.08 \\
(n=8)\end{array}$ & $\begin{array}{l}3.35 \\
(n=8)\end{array}$ & $\begin{array}{l}2.72 \\
(n=7)\end{array}$ \\
\hline $\begin{array}{l}\text { Anti-fracking } \\
\text { UK }\end{array}$ & $\begin{array}{l}4.0 \\
(n=4)\end{array}$ & $\begin{array}{l}2.86 \\
(n=4)\end{array}$ & $\begin{array}{l}3.6 \\
(n=2)\end{array}$ & $\begin{array}{l}2.88 \\
(n=2)\end{array}$ \\
\hline $\begin{array}{l}\text { Pro-exploration } \\
\text { Neuchâtel }\end{array}$ & $\begin{array}{l}1.33 \\
(n=3)\end{array}$ & $\begin{array}{l}2.19 \\
(n=4)\end{array}$ & $\begin{array}{l}3.39 \\
(n=4)\end{array}$ & $\begin{array}{l}2.23 \\
(n=4)\end{array}$ \\
\hline $\begin{array}{l}\text { Anti-fracking } \\
\text { Neuchâtel }\end{array}$ & $\begin{array}{l}2.72 \\
(n=18)\end{array}$ & $\begin{array}{l}3.00 \\
(n=18)\end{array}$ & $\begin{array}{l}3.71 \\
(n=13)\end{array}$ & $\begin{array}{l}2.63 \\
(n=14)\end{array}$ \\
\hline $\begin{array}{l}\text { Pro-exploration } \\
\text { Bern }\end{array}$ & $\begin{array}{l}1.5 \\
(n=2)\end{array}$ & $\begin{array}{l}2.52 \\
(n=3)\end{array}$ & $\begin{array}{l}3.07 \\
(n=3)\end{array}$ & $\begin{array}{l}2.23 \\
(n=3)\end{array}$ \\
\hline $\begin{array}{l}\text { Anti-fracking } \\
\text { Bern }\end{array}$ & $\begin{array}{l}2.5 \\
(n=14)\end{array}$ & $\begin{array}{l}2.61 \\
(n=14)\end{array}$ & $\begin{array}{l}3.36 \\
(n=13)\end{array}$ & $\begin{array}{l}2.53 \\
(n=13)\end{array}$ \\
\hline $\begin{array}{l}\text { Pro-exploration } \\
\text { Vaud }\end{array}$ & $\begin{array}{l}1.5 \\
(n=2)\end{array}$ & $\begin{array}{l}2.04 \\
(n=3)\end{array}$ & $\begin{array}{l}3.35 \\
(n=3)\end{array}$ & $\begin{array}{l}2.43 \\
(n=3)\end{array}$ \\
\hline $\begin{array}{l}\text { Anti-fracking } \\
\text { Vaud }\end{array}$ & $\begin{array}{l}2.5 \\
(n=8)\end{array}$ & $\begin{array}{l}2.84 \\
(n=7)\end{array}$ & $\begin{array}{l}2.69 \\
(n=8)\end{array}$ & $\begin{array}{l}2.55 \\
(n=8)\end{array}$ \\
\hline
\end{tabular}

Note: "n" per cell indicate the number of respondents to the respective survey question. Differences in number between coalition membership (Tables 1-4) and numbers displayed here (Table 5) stem from the fact that survey partners did not answer all questions.

In the UK, the largest coalition is pro-exploration and contains the most powerful UK Government actors (Table 2). It cannot be described simply as a 'pro-fracking' coalition, since the common position is one that favours the development of fracking potential. It is opposed by a smaller coalition which can be described as 'anti-fracking' ${ }^{4}$ While it consists of only 6 actors (in contrast to 25 pro-exploration members), they are central to attempts to impede subnational fracking projects.

Table 2: UK pro-exploration and anti-fracking coalitions

\begin{tabular}{|l|l|}
\hline Pro-exploration (25) & Anti-fracking (6) \\
\hline $\begin{array}{l}\text { UK government bodies: Cabinet, Department of Energy and Climate } \\
\text { Change DECC, Office of Unconventional Gas and Oil (OUGO), } \\
\text { Environment Agency, Health and Safety Executive. }\end{array}$ & $\begin{array}{l}\text { Party. } \\
\text { NGOs: Campaign } \\
\text { to Protect Rural } \\
\text { England, Frack off, }\end{array}$ \\
\hline
\end{tabular}




\begin{tabular}{|l|l|}
\hline Political parties: Conservative Party, Labour Party, Liberal & $\begin{array}{l}\text { Friends of the Earth, } \\
\text { Democrats, The Energy and Climate Change Committee of the House } \\
\text { af WWF UK. } \\
\text { of Commons. }\end{array}$ \\
Companies: Cuadrilla, IGas Energy, Centrica, Total, Shell, National \\
Cendre Manchester. \\
Grid, United Kingdom Onshore Operators Group, Oil \& Gas UK, \\
Chemical Industries Association. \\
NGO: No Hot Air. \\
Science: Royal Academy of Engineering, Royal Society, British \\
Geological Survey, CNG Services, Geological Society, Policy \\
Exchange.
\end{tabular}

In all three Swiss cantons the largest coalition is opposed to fracking (Tables 3-5). The coalitions include actors from the cantonal administration, green and centre-left political parties, municipalities and NGOs. In all three, a smaller coalition is not explicitly pro-fracking, but is opposed to a ban and labelled as 'pro-exploration coalition'. It usually includes the economy-friendly Swiss People's Party (unless in Neuchâtel), Radical Democratic Party, and energy firms interested in specific gas exploration projects (the oil and gas industry more generally is more reticent about engagement). Federal administrative actors are split among both coalitions (with offices responsible for the Environment and for Spatial Planning in the anti-fracking coalition, and for Energy and for Topology in pro-exploitation). The anti-fracking coalitions more successfully translate their beliefs into policy outputs. While Neuchâtel and Bern are planning a ban, actors agreed on a moratorium in Vaud, where the size and constitution of the two coalitions is more balanced.

Table 3: Neuchâtel pro-exploration and anti-fracking coalitions

\begin{tabular}{|c|c|}
\hline Pro-exploration (4) & Anti-fracking (25) \\
\hline $\begin{array}{l}\text { Federal } \\
\text { administration: } \\
\text { Federal Office of } \\
\text { Topography, } \\
\text { Federal Office of } \\
\text { Energy. } \\
\text { Political parties: } \\
\text { Radical } \\
\text { Democratic Party. } \\
\text { Companies: } \\
\text { Celtique Energie } \\
\text { Ltd. }\end{array}$ & $\begin{array}{l}\text { Cantonal administration: Cantonal Government, Cantonal } \\
\text { Parliament, Department of Spatial Development and the } \\
\text { Environment, Office of Consumption and Veterinary, Office of } \\
\text { Energy and Environment. } \\
\text { Federal administration: Federal Office for the Environment, Federal } \\
\text { Office for Spatial Development. } \\
\text { NGOs: Pro Natura, WWF, Collectif Val-deTravers, Greenpeace, } \\
\text { Association of Friends of Farm "Robert", House of Nature } \\
\text { Association, Fishers' Society of Bass-Areuse. } \\
\text { Cantonal Parties: Social Democratic Party, Swiss People's Party, } \\
\text { Swiss Labor Party, Christian Democratic Party, Green Party, } \\
\text { Solidarity Party, Liberal Green Party. } \\
\text { Municipalities: City Council Neuchâtel, City Council La-Chaux-de } \\
\text { Fonds, City Council Val-de-Travers. } \\
\text { Science: University of Neuchâtel. }\end{array}$ \\
\hline
\end{tabular}


Table 4: Bern pro-exploration and anti-fracking coalitions

\begin{tabular}{|c|c|}
\hline Pro-exploration (5) & Anti-fracking (17) \\
\hline $\begin{array}{l}\text { Federal } \\
\text { administration: } \\
\text { Federal Office of } \\
\text { Topography. } \\
\text { Cantonal parties: } \\
\text { Liberal } \\
\text { Democratic Party, } \\
\text { Swiss People's } \\
\text { Party. } \\
\text { Companies: Swiss } \\
\text { Oil and Gas } \\
\text { Company (SEAG), } \\
\text { Geo Explorers Ltd } \\
\text { (Oil and Gas } \\
\text { Company). }\end{array}$ & $\begin{array}{l}\text { Cantonal administration: Department of Construction, Transport } \\
\text { and Energy. } \\
\text { Federal administration: Federal Office for the Environment, Federal } \\
\text { Office for Spatial Development. } \\
\text { Companies: Energy Water Bern, Geo Energy Suisse. } \\
\text { Cantonal parties: Christian Democratic Party, Green Liberal Party, } \\
\text { Social Democratic Party, Bourgeois Democratic Party, Evangelic } \\
\text { Democratic Party, Green Party. } \\
\text { NGOs: Pro Natura, WWF, Greenpeace. } \\
\text { Municipalities: City of Thun, Municipality of Rapperswil. }\end{array}$ \\
\hline
\end{tabular}

Table 5: Vaud pro-exploration and anti-fracking coalitions

\begin{tabular}{|l|l|}
\hline Pro-exploration (6) & Anti-fracking (15) \\
\hline Federal & Cantonal administration: Cantonal Parliament, Cantonal \\
Federal Office of & Government, Cantonal Department of Spatial Planning and \\
Environment, Cantonal Office for Energy. \\
Federal Office for & Municipalities: City Council Lausanne. \\
Energy. & Federal administration: Federal Office for Spatial Development, \\
Companies: & NGOs: Pro Natura. \\
Petrosvibri. & Cantonal Parties: Social Democratic Party, Solidarity Party, Swiss \\
NGOs: & Labor Party, Green Party, Christian Democratic Party, Green Liberal \\
Employers' & Party, Free Vaud Party. \\
Association Vaud. & \\
Cantonal Parties: & \\
Liberal & \\
Democratic Party, & \\
Swiss People's & \\
Party. & \\
\hline
\end{tabular}

\section{How do advocacy coalitions exchange information?}

In a new issue such as fracking, one key aim of actors is to exchange and use technical/ scientific information to exploit or downplay unusually high levels of uncertainty, and to use political information to address ambiguity: influencing how actors frame problems and decide how they should be addressed, and identifying the most promising strategies. This focus is particularly useful to explain why the UK government pursues a tentative pro-fracking policy: 
it has a clear way to frame the policy problem and seek to persuade other actors (low ambiguity) but not to settle how actors should weigh up the potential environmental costs and economic benefits (high uncertainty).

In both countries, there is a sense of 'unfinished business'. First, there is scientific uncertainty in relation to activities, such as drilling techniques for unconventional gas development, with a limited track record. Opponents of fracking try to exploit uncertainty to challenge policy. Yet, policymakers make key decisions despite their limited abilities to understand scientific reports or articulate risk, in part by relying on information from sources they trust. Second, in multi-level systems, in which a range of policy instruments can be adopted by different governments, there is uncertainty about who makes key decisions, or how many authorities come together to produce policy. Both types of uncertainty are compounded by ambiguity: as a policy problem, fracking can be 'framed' as an economic opportunity or an environmental disaster; as a policy responsibility, it can be defined in terms of national leadership or local veto. Indeed, opponents have gained traction by highlighting the UK Government's lack of respect for local policymaking (Bomberg, 2015).

This process of persuasion plays out in relation to the balance between potential risk and reward. The reward relates primarily to the importance of 'energy security', when a state is able to reduce its reliance on energy imported from other countries, and economic gains related to: tax revenue from mineral extraction; an improved balance of payments; capital investment and employment; regeneration in areas with low economic activity; and, lower energy bills. There is also a potential environmental gain if the main effect of local shale gas extraction is to rely less on imported fossil fuels (Bradshaw, 2014; Tosun and Lang, 2016).

The risk relates primarily to environmental problems - over and above the risks to climate change of burning fossil fuels - including the: contribution of methane gas leaked during production to climate change; groundwater pollution, when the chemicals used to fracture shale enter the water supply; greater risk of earthquakes/ tremors from fracturing; and, air and noise pollution to local areas (Bradshaw, 2014; White et al., 2014: 13-6; Jones et al., 2013: 387; Friends of the Earth, 2013). This risk is not shared equally across populations (Jones et al., 2014a: 512).

\section{Unsuccessful attempts to remove uncertainty and promote a positive image of fracking}

Pro-fracking actors seek to downplay scientific uncertainty (Newig et al., 2005; Ingold and Gschwend, 2014). The UK government frames the issue in terms of 'energy security, decarbonisation and economic growth' (DECC, 2014a: 4). It has sought information from its trusted sources, professional scientific bodies and businesses, to support its pro-exploration stance and frame the issue as an economic benefit with low risk when well regulated (British Geological Society, 2014; Andrews, 2013: 3; Postbox, 2013; White et al., 2014: 6-7; Royal Society and The Royal Academy of Engineering, 2012: 4).

In Switzerland, on the federal government level, the Federal Office for the Environment (BAFU) is the main responsible actor. It formed a broad expert commission working on a report covering the technology of hydraulic fracturing, the geological potential, the regulatory 
context, environmental aspects, and economical and societal aspects. Whereas the parts on technology, geology and environment are supposed to inform the government and its administration on aspects of scientific uncertainty, the parts on regulatory context and economical and societal aspects are to deal with political uncertainties.

In both countries, the production and sharing of technical information is not enough to settle the matter. Rather, the 'devil shift' suggests that anti-fracking coalitions will not accept technical information at face value (actors in one coalition 'demonise' the actions of another Sabatier et al., 1987), while genuine uncertainty about the future cannot be resolved by estimates on the impacts of fracking. Instead, current developments offer a snapshot of: a debate that has yet to be resolved; and, the nature of each coalition, including the extent to which they seek to resolve policy debates by sharing information. Some issues are addressed by the generation and sharing of technical or scientific information to attempt to reduce uncertainty about the risks and rewards of fracking. Policy uncertainties can also be addressed by sharing political information about where and how best to lobby, how policymakers can engage with groups to produce negotiated outcomes, and how groups can 'frame' the issue. When actors mobilise to influence policy, they may only share certain types of information with certain actors. For example, actors may only share information regarding political strategies with their allies, but might share technical information more widely, to engage in debate with their competitors.

\section{The evidence on information exchange within and between coalitions}

We assess the intensities by which coalition members exchange technical and political information with their allies and opponents (Table 6; online Appendix I, question 7). In the UK, densities of political information exchange are consistently higher within than across coalitions. This confirms a broad ACF assumption: actors with similar beliefs engage in a nontrivial degree of coordination within their coalitions (Sabatier, 1998; Schlager, 1995). We further find that the pro-exploration coalition is the most active, and that it shares some information across coalitions. It provides the anti-fracking coalition with some political information and more technical information. This may indicate the willingness of the proexploration coalition to integrate the opposing coalition into the process of finding a viable policy solution. Given that most members of the anti-fracking coalition take some part in actions against local fracking projects (Jones et al., 2013: 389; Beebeejaun, 2013), providing these actors with political information might be a strategy to reduce further protest. The relatively high amount of cross-coalition exchange of technical information (0.15) suggests that it is more 'politically neutral' than political information, but also that it is important for actors to deal with scientific uncertainty.

This activity of the UK pro-exploration coalition might stem from the fact that leading administrative actors such as the DECC and the OUGO belong to this coalition. It could also indicate that the pro-exploration coalition attempts to convince members of the anti-fracking coalition to join their efforts to allow fracking if accompanied by strong pro-environmental legislation and meaningful involvement of local communities. 
Table 6: Sharing political and technical information

\begin{tabular}{|l|l|l|l|l|l|l|}
\hline & $\begin{array}{l}\text { Political } \\
\text { information }\end{array}$ & $\begin{array}{l}\text { Pro- } \\
\text { exploratio } \\
\text { n }\end{array}$ & $\begin{array}{l}\text { Anti- } \\
\text { fracking }\end{array}$ & $\begin{array}{l}\text { Technical } \\
\text { information }\end{array}$ & $\begin{array}{l}\text { Pro- } \\
\text { exploratio } \\
\text { n }\end{array}$ & $\begin{array}{l}\text { Anti- } \\
\text { fracking }\end{array}$ \\
\hline UK & $\begin{array}{l}\text { Pro- } \\
\text { developmen }\end{array}$ & 0.12 & 0.06 & $\begin{array}{l}\text { Pro- } \\
\text { developmen } \\
\text { t }\end{array}$ & 0.24 & 0.15 \\
\hline $\begin{array}{l}\text { Anti- } \\
\text { fracking }\end{array}$ & 0.02 & 0.11 & $\begin{array}{l}\text { Anti- } \\
\text { fracking }\end{array}$ & 0.09 & 0.19 \\
\hline NE & $\begin{array}{l}\text { Pro- } \\
\text { exploration }\end{array}$ & 0.13 & 0.17 & $\begin{array}{l}\text { Pro- } \\
\text { exploration }\end{array}$ & 0.38 & 0.24 \\
\hline & $\begin{array}{l}\text { Anti- } \\
\text { fracking }\end{array}$ & 0.00 & 0.21 & $\begin{array}{l}\text { Anti- } \\
\text { fracking }\end{array}$ & 0.14 & 0.20 \\
\hline BE & $\begin{array}{l}\text { Pro- } \\
\text { exploration }\end{array}$ & 0.12 & 0.13 & $\begin{array}{l}\text { Pro- } \\
\text { exploration }\end{array}$ & 0.08 & 0.13 \\
\hline & $\begin{array}{l}\text { Anti- } \\
\text { fracking }\end{array}$ & 0.13 & 0.15 & $\begin{array}{l}\text { Anti- } \\
\text { fracking }\end{array}$ & 0.08 & 0.12 \\
\hline & & & 0.08 & $\begin{array}{l}\text { Pro- } \\
\text { exploration }\end{array}$ & 0.08 & 0.10 \\
\hline VD & $\begin{array}{l}\text { Pro- } \\
\text { exploration }\end{array}$ & 0.06 & $\begin{array}{l}\text { Anti- } \\
\text { fracking }\end{array}$ & 0.08 & 0.14 \\
\hline & $\begin{array}{l}\text { Anti- } \\
\text { fracking }\end{array}$ & 0.10 & 0.17 & & \\
\hline
\end{tabular}

The effect of macro-institutional factors on subsystem dynamics

In the UK, there is some cross-coalition exchange of information (Table 6), but it is consistently less intense than within-coalition information exchange. Does this pattern correspond to Lijphart's (1999) expectation of conflict and competition in majoritarian systems, or to the more consensual types of interactions (Kriesi et al. 2006)? It is only by comparing systems that we can make a firm judgement about these patterns. We find 'face value' consensus policymaking at the UK national level, but only a comparison with a country like Switzerland allows us to identify a meaningful reference point.

Indeed, some patterns of information sharing are different in the Swiss subnational constituencies (cantons). There is no clear coalition pattern because, in all three cantons, both political and technical information are exchanged within as well as across coalitions on a scale not found in the UK. More specifically, information exchange from the pro-exploration actors to the anti-fracking coalition is consistently more intense than information exchange within each of these two coalitions. On a general level, this corresponds to the expectation of more fragmented policy-making in consensual Switzerland (Kriesi et al. 2006). Our data thus helps us identify a more subtle influence of macro-political context than provided by Lijphart (1999): in the relatively competitive atmosphere of majoritarian systems like the UK, actors seem more likely to internalise the supply of information, whereas cross-coalition exchange is more common in consensus systems like the Swiss one. 


\section{Discussion and conclusion: the UK's 'majoritarian' institutions have not produced a majoritarian style}

It would have been reasonable to expect policy change to be far greater and faster in the UK compared to Switzerland. In reality, the UK government has pursued a tentatively pro-fracking position within a multi-level system in which subnational actors are less in favour of development, while Swiss cantons have produced the less equivocal policy change by prohibiting fracking development. Policy outcomes in both countries are remarkably similar: national governments have not imposed the development of commercial fracking, sub-national governments are introducing fracking restrictions and bans, and (with one very recent exception) local communities have demonstrated high and, so far, successful resistance.

A combination of macro-political institutions and policy choices does not explain these developments, but the former has some impact on the subsystem dynamics crucial to policy development. Our analysis shows a sense of nascent policymaking (Ingold et al, 2016; Cairney et al, 2016) with not-yet clearly defined and sometimes fragmented coalitions (which correspond to the situation at the time of our analysis and might change in the future). This coalition structure is combined with some level of agreement between pro- and anti-fracking organizations about treading carefully via some pro-environmental regulation. The UK dynamic can be explained by an imbalanced coalition structure where one coalition seems to dominate the process, but is only tentatively in favour of commercial development, and prefers a careful assessment of economic potential and environmental risks. Even though this coalition does not perceive serious environmental problems, it still agrees with the smaller anti-fracking coalition about the introduction of pro-environmental regulations.

Further, what we see, so far, is an imbalance between coalitions at the UK central level only. We need more survey data on the multi-level dimension to confirm our initial finding, based on the analysis of events and policy documents, that this imbalance is overturned at devolved levels. Decisions against fracking development by devolved governments (Scotland, Wales, Northern Ireland) would, to all intents and purposes, be binding. Decisions by local authorities in England have more potential to be overturned by the UK Government, or pro-fracking decisions may be more influenced by the UK's combination of regulations, planning guidance, and financial incentives to encourage development.

In other words, the UK government is at an early stage of trying to negotiate local opposition in England while also pursuing a national strategy. This process is still unfolding, and the extent to which the UK government may be willing to impose its will more strongly (or offer greater economic incentives to local communities) is unclear, as is the future of anti-fracking coalitions which remain fragmented, particularly in local areas. We are describing a snapshot in time, and the next snapshot may differ.

In Switzerland, it is currently unclear if the national level will produce any regulatory guidelines or whether the issue is kept at the sub-national level (although current developments suggest that national actors would produce a moratorium similar to that of relevant cantons Ingold and Fischer, 2016). At the moment, this seems less important than the decisions of each 
relevant canton to prohibit commercial development. Neuchâtel and Bern wish to ban the application of fracking techniques whereas Vaud may extend a moratorium. Those outputs reflect negotiations and debates within and across coalitions focused on canton-level policymaking. In Neuchâtel and Bern, two larger anti-fracking coalitions, dominated by regional public authorities and centre-left parties, promoted the planned ban. In Vaud, public authorities were split across the two opposing coalitions. This slightly more even situation led to Vaud's more temporary moratorium.

Both countries process policy through subsystems, but the nature of information exchange within them differs significantly. Generally, coalition members tend to share information among each other and less so with their competitors. However, this effect is far more pronounced in the UK, reflecting a more competitive atmosphere. There is some exchange of political information from the larger coalition to other actors, perhaps to encourage the development of common ground, or seek to influence other actors; and the subsystem-wide exchange of technical information, to reflect widespread sharing of information in relation to scientific and regulatory uncertainty. In Switzerland, the pro-exploration coalitions appear to be less well organized - based on relatively low levels of information exchange within them but there are still more significant flows of information from actors in the pro-exploration coalition to anti-fracking coalition members than within some of the coalitions.

This comparative analysis helps us take the system/subsystem debate forward by pinpointing the effect of macro-level political systems on policymaking in subsystems. We also improve the value of the Advocacy Coalition Framework by applying it to new circumstances and modifying aspects of the framework itself. First, we show that the ACF is a suitable framework for studying policy outputs, change and outcomes at different levels. When comparing Switzerland and UK through the lens of the ACF we were able to conduct not only a crosscountry, but also a multi-level comparison. Focusing on subsystems dealing with the same issue, and potentially producing similar policy solutions, enables us to conduct research at multiple scales (Sabatier, 1999). Second, this research shows convincingly how institutional factors impact policy styles and processes (such as coalition formation and coordination) more directly than policy outputs or outcomes. The triangulation between institutions, politics and policy seems a promising pathway for future comparative research applying the ACF (see also Henry et al., 2014). Third, our results emphasize the link between political system and subsystem, showing that the dynamics of the latter help researchers understand how policy outputs and change occur.

Overall, the case of hydraulic fracturing demonstrates a broader point about the study of politics: we would produce a limited explanation of events if we relied simply on a comparison between majoritarian and consensus systems to explain differences in policymaking and outcomes. Instead, it is important to identify the common problems that governments face, and the extent to which coalitions form in similar ways to cooperate with each other and compete with others to determine the ways in which governments solve them. In that sense, each country exhibits similar circumstances: the environmental costs are unclear but worrying; the economic rewards are not as high as in the US and are diminishing to reflect major reductions in oil and gas prices; and, there is no obvious way to translate public support in principle for development 
(which is apparent but diminishing in the UK - O'Hara et al, 2015; Cairney, 2015), and national level oversight, into regionally specific fracking, because local publics and policymakers will generally oppose development. Although the UK Government appears to be more willing and able to do it, we miss a lot by assuming rather than demonstrating that its political will translates into major policy change.

\section{References}

Adam, Silke and Kriesi, Hans-Peter. (2007) 'The Network Approach', in P. Sabatier (ed.) Theories of the Policy Process, second edition. Cambridge MA: Westview Pres

Andrews, I.J. 2013. The Carboniferous Bowland Shale gas study. https://www.gov.uk/government/uploads/system/uploads/attachment_data/file/226874/BGS_DECC_ BowlandShaleGasReport_MAIN_REPORT.pdf

Batagelj, Vladimir, and Mrvar, Andrej. 1996. Pajek - Program for Large Network Analysis. University of Ljubljana.

Baumgartner, Frank, and Jones, Bryan. 1993. Agendas and Instability in American Politics. Chicago, IL: Chicago University Press.

BBC News. 2014. Shale gas: George Osborne proposes north of England fund. 8 November, http://www.bbc.co.uk/news/uk-england-29968603

BBC News. 2016. Fracking decision in North Yorkshire reignites intense debate. 24.5.16 http://www.bbc.co.uk/news/business-36366302

Beebeejaun, Yasminah. 2013. The Politics of Fracking. Political Insight 4: 18-21. http://onlinelibrary.wiley.com/doi/10.1111/2041-9066.12032/full

BGS (British Geological Survey). 2014. How much shale gas do we have? http://www.bgs.ac.uk/research/energy/shaleGas/howMuch.html

Bomberg, Elizabeth. 2015. Shale We Drill?, Journal of Environmental Policy \& Planning, Early view DOI: 10.1080/1523908X.2015.1053111

Bradshaw, Michael. 2014. Hydraulic Fracturing: its growth and risks. Warwick: University of Warwick

Cairney, Paul. 2011. The New British Policy Style. Political Studies Review, 9, 2, 208-20

Cairney, Paul. 2012. Understanding Public Policy. Basingstoke: Palgrave.

Cairney, P. (2015) 'What does the British public think about fracking, and how does it matter?', Politics and Public Policy, https://paulcairney.wordpress.com/2015/01/25/what-does-the-british-public-thinkabout-fracking-and-how-does-it-matter/

Cairney, Paul. 2016. The Politics of Evidence Based Policy Making. London: Palgrave.

Cairney, P., Fischer, M., and Ingold, K. (2016) 'Hydraulic fracturing policy in the UK: coalition, cooperation and opposition in the face of uncertainty', in Weible, Christopher, Heikkila, Tanya, Ingold, 
Karin, and Fischer, Manuel (eds.) Comparing Coalition Politics: Policy Debates on Hydraulic Fracturing in North America and Western Europe. Palgrave

Cairney, Paul. and Widfeldt, Anders. 2015. Is Scotland a Westminster style Majoritarian Democracy or a Scandinavian-style Consensus Democracy? Regional \& Federal Studies, 25:1, 1-18

DECC (Department of Energy and Climate Change). 2012. Providing oil and gas exploration and production data. https://www.gov.uk/government/policies/providing-regulation-and-licensing-ofenergy-industries-and-infrastructure/supporting-pages/providing-oil-and-gas-exploration-andproduction-data

DECC. 2013a. Onshore oil and gas exploration in the UK. https://www.gov.uk/government/uploads/system/uploads/attachment_data/file/265978/Onshore_UK oil_and_gas_exploration_all_countries_Dec13.pptx

DECC. 2013b. Estimates of shale gas resource in North of England. 27 June https://www.gov.uk/government/news/estimates-of-shale-gas-resource-in-north-of-englandpublished-alongside-a-package-of-community-benefits

DECC. 2014a. Underground Drilling Access: Consultation on Proposal for Underground Access for the Extraction of Gas, Oil or Geothermal Energy. https://www.gov.uk/government/uploads/system/uploads/attachment_data/file/313576/Consultation_o n Underground Drilling Access final web version.pdf

DECC. 2014b. Underground Drilling Access: Government Response to the Consultation on Proposal for Underground Access for the Extraction of Gas, Oil or Geothermal Energy. https://www.gov.uk/government/uploads/system/uploads/attachment_data/file/358521/Government_R esponse_FINAL.pdf

DECC. 2014c. Guidance: About shale gas and hydraulic fracturing (fracking). https://www.gov.uk/government/publications/about-shale-gas-and-hydraulic-fracturing-fracking

Dearing, James, and Rogers, Everett. 1997. Agenda Setting. London: Sage

Doreian, Patrick, and Mrvar, Andrej. 2009. Partitioning signed social networks. Social Networks 31: 111.

Fink, Matthias, and Harms, Rainer. 2012. Contextualizing the relationship between self-commitment and performance. Entrepreneurship \& Regional Development: An International Journal 24 (3-4): 16179.

Fischer, Manuel. 2014. Coalition Structures and Policy Change in a Consensus Democracy. The Policy Studies Journal 42 (3): 344-66.

Fischer, Manuel. 2015. Institutions and Coalitions in Policy Processes: a Cross-Sectoral Comparison. Journal of Public Policy 35 (2): 245-68

Flinders, Matthew. 2010. Democratic Drift. Oxford: Oxford University Press. 
Friends of the Earth. 2013. Briefing: Unconventional, unnecessary and unwanted. http://www.foe.co.uk/resource/briefings/shale gas.pdf

Gallagher, M., Laver, M. and Mair, P. (1995) Representative Government in Modern Europe. New York: McGraw-Hill

The Guardian. 2015. 'George Osborne demands rapid progress on fracking' 26 January http://www.theguardian.com/environment/interactive/2015/jan/26/george-osborne-fracking-letter

Henry, Adam, and Ingold, Karin. 2011. Network Methods for the Discovery of Advocacy Coalitions. Presented and the Midwest Political Science Conference, April 2011

Henry, Adam Ingold, Karin, Nohrstedt, Daniel, and Weible, Christopfer. 2014. Policy Change in Comparative Contexts. Applying the Advocacy Coalition Framework Outside of Western Europe and North America. Journal of Comparative Policy Analysis: Research and Practice 16(4, SI): 299-312. DOI:10.1080/13876988.2014.941200.

HM Treasury. 2013. Shale gas: government unveils plan to kick start investment with generous new tax breaks. 19 July https://www.gov.uk/government/news/shale-gas-government-unveils-plan-to-kickstart-investment-with-generous-new-tax-breaks

Ingold, Karin. 2011. Network Structures within Policy Processes. Policy Studies Journal 39 (3): 43559

Ingold, Karin, and Manuel Fischer. 2016. "Belief conflicts and coalition structures driving sub-national policy responses: the case of Swiss regulation of unconventional gas development." In Comparing Coalition Politics: Policy Debates on Hydraulic Fracturing in North America and Western Europe, ed. C. Weible, T. Heikkila, K. Ingold and M. Fischer: Palgrave

Ingold, K., Fischer, M. and Cairney, P. (2016) 'Drivers for policy agreement in nascent subsystems: An Application of the Advocacy Coalition Framework to Fracking policy in Switzerland and the UK', Policy Studies Journal, forthcoming

Ingold, Karin, and Gschwend, Muriel. 2014. Science in Policy Making. West European Politics 37 (5): 993-1018

Jenkins-Smith, Hank, Nohrstedt, Daniel, and Weible, Christopher. 2014. The Advocacy Coalition Framework. in Sabatier, Paul, and Weible, Christopher. (eds.) Theories of the Policy Process 3rd edition. Chicago: Westview Press

Jones, Peter, Hillier, David and Comfort, Daphne. 2013. Fracking and public relations. Journal of Public Affairs 13: 384-390

Jones, Peter, Hillier, David and Comfort, Daphne. 2014a. Fracking for shale gas in the UK. Journal of Property Investment \& Finance 32 (5): 505 - 517.

Jones, Peter, Hillier, David and Comfort, Daphne. 2014b. Fracking in the UK. Property Management 32 (4): $352-361$.

Jordan, Grant and Cairney, Paul. 2013. What is the 'Dominant Model' of British Policy Making? . British Politics 8(3): 233-259 
Kingdon, John. 1984. Agendas, Alternatives and Public Policies. New York, NY: Harper Collins.

Knoke, David. 1993. Networks of Elite Structure and Decision Making. Sociological Methods \& Research 22 (1): 22-45.

Kriesi, Hans-Peter, Adam, Silke, and Jochum, Margit 2006. Comparative analysis of policy networks in Western Europe. Journal of European Public Policy 13 (3): 341-61.

Lane, Jan-Erik. 2001. Introduction: Switzerland - Key Institutions and Behavioural Outcomes. West European Politics 24 (2): 1-18.

Laumann, Edward, Marsden, Peter, and Prensky, David. 1983. The boundary specification problem in network analysis. in Burt, Ronald, an Minor, Michael. Applied network analysis: A methodological introduction. London, UK: Sage Publications, 18-34.

Lijphart, Arend. 1984. Democracies. New Haven, CT: Yale University Press

Lijphart, Arend. 1999. Patterns of democracy. New Haven: Yale University Press.

Linder, Wolf, and Adrian Vatter. 2001. Institutions and outcomes of Swiss federalism. West European Politics 24 (2): 95-122.

Lubell, Mark. 2003. "Collaborative Institutions, Belief-Systems, and Perceived Policy Effectiveness." Political Research Quarterly 56 (3): 309-23.

Lubell, Mark. 2013. Governing Institutional Complexity. Policy Studies Journal 41 (3): 537-59.

Mahoney, Christine. 2007. Networking vs. allying. Journal of European Public Policy 14 (3): 366-83.

Metz, Florence, and Ingold, Karin. 2014. Policy Instrument Selection under Uncertainty. Paper to the Swiss Political Science Association, Annual Meeting, January 2014, University of Bern

Newig, Jens, Claudia Pahl-Wostl, and Katja Sigel. 2005. The role of public participation in managing uncertainty in the implementation of the Water Framework Directive. European Environment 15 (6): $333-43$.

Nooy, Wouter De, Mrvar, Andrej, and Batagelj, Vladimir. 2005. Exploratory Social Network Analysis with Pajek. New York: Cambridge University Press.

O'Hara, S., Humphrey, M., Andersson-Hudson, J. and Knight, W. (2015) 'Public Perception of Shale Gas Extraction in the UK' (Nottingham: University of Nottingham) https://www.scribd.com/doc/131787519/public-perceptions-of-shale-gas-in-the-UK-September-2015pdf

Papadopoulos, Yannis. 2001. How does direct democracy matter? West European Politics 24 (2): 3558.

Postbox. 2013. $\quad$ UK $\quad$ Shale Gas $\quad$ Potential, July. http://www.parliament.uk/documents/post/ShaleGas_POSTbox.pdf

Prime Minister's Office. 2014. 'Local councils to receive millions in business rates from shale gas developments', 13 January https://www.gov.uk/government/news/local-councils-to-receive-millionsin-business-rates-from-shale-gas-developments 
Richardson, J. (ed.) (1982) Policy Styles in Western Europe. London: Allen \& Unwin

The Royal Society and The Royal Academy of Engineering. 2012. Shale gas extraction in the UK, June. https://royalsociety.org/ /media/policy/projects/shale-gas-extraction/2012-06-28-shale-gas.pdf

Sabatier, Paul A.1999. Fostering the development of policy theory, in: P. A. Sabatier (Ed) Theories of the Policy Process. Boulder, Colorado: Westview Press, 261-276.

Sabatier, Paul A. 1998. The advocacy coalition framework: revisions and relevance for Europe. Journal of European Public Policy 5(1): 98-130.

Sabatier, Paul. 1988. An Advocacy Coalition Framework of Policy Change and the Role of PolicyOriented Learning Therein. Policy Sciences 21(2-3): 129-126.

Sabatier, Paul, and Weible, Christopher. 2007. The Advocacy Coalition Framework. in Sabatier, Paul (ed.) Theories of the Policy Process, second edition. Boulder, Colorado: Westview Press, 189-222.

Sabatier, Paul A., and Jenkins-Smith, Hank C. 1993. Policy Change and Learning: An Advocacy Coalition Approach. Boulder, Colorado: Westview Press.

Sabatier, Paul, Susan Hunter, and Susan Mclaughlin. 1987. The Devil Shift. Political Research Quarterly 40: 449-476.

Schlager, Edella. 1995. Policy Making and Collective Action. Policy Sciences 28: 243-270.

Sciencewise. 2013. Public engagement in shale gas and oil developments. http://www.sciencewiseerc.org.uk/cms/public-engagement-in-shale-gas-and-oil-developments/

Sigel, Katja, Bernd Klauer, and Claudia Pahl-Wostl. 2010. Conceptualising uncertainty in environmental decision-making. Ecological Economics 69 (3): 502-10.

Thorlakson, Lori. 2003. Comparing Federal Institutions. West European Politics 26 (2): 1-22.

Tosun, Jale, and Lang, Achim. 2016. The Politics of Hydraulic Fracturing in Germany. in Weible, Christopher, Heikkila, Tanya, Ingold, Karin, and Fischer, Manuel.(eds.) Comparing Coalition Politics: Policy Debates on Hydraulic Fracturing in North America and Western Europe. Palgrave.

Tsebelis, George 1995. Decision Making in Political Systems. British Journal of Political Science 25: 289-325.

Vatter, Adrian. 2009. Lijphardt expanded. European Political Science Review 1(1): 125-154.

Walker, Warren E, Robert J Lempert, and Jan H Kwakkel. 2013. Deep Uncertainty. In Saul I Gass and Michael C Fu. (eds.) Encyclopedia of Operations Research and Management Science. Springer US, 395-402.

Weible, Christopher, and Sabatier, Paul A. 2005. Comparing Policy Networks: Marine Protected Areasin California. Policy Studies Journal 33 (2).

Weible, Christopher, Sabatier, Paul A., and McQueen, K. 2009. Themes and Variations: Taking Stock of the Advocacy Coalition Framework. Policy Studies Journal 37(1): 121-41. 
White, Edward., Fell, Mike, Smith, Louise. and Keep, Matthew. 2014. Shale gas and fracking, House of Commons Library SN/SC/6073. www.parliament.uk/briefing-papers/sn06073.pdf

Zahariadins, Nikolaos. 2007. The Multiple Streams Framework. In Sabatier, Paul, and Weible, Christopher. (eds.) Theories of the Policy Process 3rd edition. Chicago: Westview Press 


\section{Appendix I - Survey questions}

Note: Original surveys are in English (UK), German (Bern) and French (Neuchâtel, Vaud). Surveys in the three Swiss cantons and the UK were exactly the same (except of the actors' list presented to the survey participants, see Tables 2-5 for actor details per case). The example is from canton of Neuchâtel.

\section{Question 6: Agreement and disagreement between actors}

The political debate on the regulation of hydraulic fracturing in the canton of Neuchâtel involved a big number of actors. The following table (list of actors, consult here actors in Tables 2-5) contains a list as complete as possible of the relevant actors. Please check all actors with whom your organization mainly agreed upon policy measures to be taken to regulate hydraulic fracturing in the canton of Neuchâtel (second column). In a next step, please indicate all actors with whom your organization mainly disagreed about policy measures to be taken to regulate hydraulic fracturing in the canton of Neuchâtel (third column). If there are actors missing, please add them to the bottom of the list and indicate if your organization agreed / disagreed with them.

\section{Question 7. Technical and political information exchange}

The following table shows exactly the same list of actors as before. First, please check all actors from which your organization regularly obtained technical information during the policy debate on the regulation of hydraulic fracturing in the canton of Neuchâtel. Second, please check all actors which your organization regularly provided with technical information during the policy debate on the regulation of hydraulic fracturing in the canton of Neuchâtel. Third, please check all actors from which your organization regularly obtained political information during the policy debate on the regulation of hydraulic fracturing in the canton of Neuchâtel. Fourth, please check all actors which your organization regularly provided with political information during the policy debate on the regulation of hydraulic fracturing in the canton of Neuchâtel. If there are actors missing, please add them to the bottom of the list and indicate if you obtain technical information from them, or if you provide technical information to them. 


\section{Question 9: Current problems related to fracking}

Following the opinion of your organization, please indicate the extent to which the following issues are current problems related to unconventional gas development: 1 not a problem/no concern, 2 minor problem, 3 moderate problem, 4 serious problem.

Issues to be selected:

- Contamination of ground and surface water

- $\quad$ Competition of water supplies

- $\quad$ Air pollution and air quality degradation

- $\quad$ Landscape degradation

- $\quad$ Nuisance to general public related to site development

- Destruction of public lands

- $\quad$ Patchwork of regulations across different institutional levels

- Unclear competence distribution

- $\quad$ Seismic activities

- Local specificities are not taken into account

- $\quad$ Lack of financial compensation for local communities

Question 10a: Pro-environmental fracking regulation

Below is a list of policy instruments which may be introduced for the regulation of unconventional gas development in the UK. Please indicate your organization's level of agreement with adopting each of the following policy instruments independently of what has been done in the UK thus far: 1 strongly disagree, 2 moderately disagree, 3 moderately agree, 4 strongly agree.

- $\quad$ Monitoring of water quality

- Monitoring of air emissions

- Disclosure of chemicals in fracking fluids

- $\quad$ Setbacks of wells from occupied buildings or natural features

- Quality control of designing and constructing wells

- Disposing or treating produced water

- $\quad$ Quality control of constructing well pads

- $\quad$ Mitigating risks from induced seismic activity 
- Mitigating risks and nuisances to the general public caused by truck traffic, noise, and light from well site operations

- Funding scientific research relating to environmental impacts of unconventional gas operations

Question 10b: Favorite concession regime/ stop fracking

Please indicate to what degree you agree with following types of concessions: 1 strongly disagree, 2 moderately disagree, 3 moderately agree, 4 strongly agree.

- $\quad$ Exploration concession

- $\quad$ Concession for site development

- Exploitation concession

- $\quad$ Moratorium

- $\quad$ Ban

\section{Question 11: General attitudes/core beliefs}

The following statements reflect general attitudes, not related to unconventional gas development. Please indicate whether your organization agrees or disagrees with each statement: 1 strongly disagree, 2 moderately disagree, 3 moderately agree, 4 strongly agree

- $\quad$ Independence of Switzerland from other countries

- $\quad$ Economic efficiency

- $\quad$ Ecological compatibility

- $\quad$ Free market / competition

- $\quad$ Security of the population

- $\quad$ Social equity

\footnotetext{
${ }^{1}$ Note that for the questions used for coalition identification and information exchange, we are still able to use information about all actors, independently of the exact response rate. Based on the network questions on actors' agreement and disagreement as well as their information exchange ("provide with" and "receive"), we are able to deduce so-called "passive data": actors who did not answer our survey could still be mentioned by other actors with respect to agreement, disagreement or information sharing. Obviously, this data only corresponds to perceptions of the actors who answered the survey.

${ }^{2}$ Agreement and disagreement about policy design and measures to be taken has proved to be a good proxy grasping similar/divergent beliefs by one pair of actors (Weible and Sabatier, 2005; Henry and Ingold, 2011). Based on this relational data, actors with similar belief profiles can be identified and grouped within coalitions (footnote 2, Ingold 2011; Fischer 2015). In a second step, we assess core beliefs and secondary aspects of coalition members (see Table 1).

${ }^{3}$ To identify coalitions, we identify clusters of actors with similar beliefs. We rely on the 'balance' procedure in Pajek (Batagelj and Mrvar, 1996; Nooy et al., 2005). This procedure continues until reaching an arrangement closest to the ideal structure. In accordance with the ACF, the ideal structure corresponds to a data matrix partitioned in groups, with only positive within-group-ties and negative between-group-ties. Deviations from this
} 
arrangement are indicated with an error term (Doreian and Mrvar, 2009), and the solution with the lowest error term is chosen for interpretation (see Fischer 2014, 2015).

${ }^{4}$ A third, small group of research institutes - UK Energy Research Center, Chatham House - is not presented. 